\title{
LAMANYA PENGGUNAAN KATETER DENGAN KEJADIAN INFEKSI SALURAN KEMIH PADA PASIEN TERPASANG KATETER
}

\author{
Yosi Suryarinilsih*, Defiaroza, Melsy Aulia \\ Politeknik Kesehatan Kemenkes Padang, \\ Jln. Raya Siteba Padang, 25146, Indonesia \\ *)E-mail: yosiarmen@yahoo.com
}

Diterima: Agustus 2017, diterbitkan: Desember 2017

\begin{abstract}
ABSTRAK
Latar Belakang: Infeksi Saluran Kemih (ISK) merupakan salah satu infeksi nasokomial yang dapat dialami pasien rawat di rumah sakit. Salah satu faktor penyebabnya bisa dari penggunaan kateter. Tujuan Penelitian: mengetahui lamanya penggunaan kateter dengan kejadian infeksi saluran kemih. Metode: Jenis penelitiannya adalah deskriptif analitik dengan pendekatan cross sectional study. Jumlah sampel 44 orang yang ditentukan dengan cara purposive sampling dengan kriteria responden adalah pasien rawat yang dipasang kateter saat baru masuk RS dengan diagnosis utama bukan infeksi saluran kemih. Izin etik panelitian diperoleh sebelum pengambilan data dilakukan. Pengumpulan data dilakukan dari 22 Juni-22 Juli 2015 dengan menggunakan lembar observasi dan pemeriksaan spesimen urin responden ke laboratorium. Data dianalisis secara univariat dan bivariate dengan uji chi square. Hasil: ditemukan 43,2\% responden mengalami ISK, dari lamanya penggunaan kateter responden, 40,9\% tidak sesuai aturan (lebih 7 hari) dan terdapat hubungan bermakna antara lamanya penggunaan kateter dengan kejadian infeksi saluran kemih $(p<0,001)$. Kesimpulan: Pengunaan kateter yang lama memiliki hubungan yang bermakna dengan terjadinya infeksi saluran kemih pada pasien. Hasil penelitian ini dapat dijadikan dasar bagi perawat ruangan dalam merencanakan intervensi pengawasan dan penggantian kateter secara periodik bagi pasien.
\end{abstract}

Kata kunci: Kateter, infeksi saluran kemih, rumah sakit, urinalisis

\section{DURATION OF CATETER USE AND INCIDENCE OF URINARY TRACT INFECTION IN PATIENTS WITH INDWELLING CATHETER}

\section{ABSTRACT}

Background: Urinary Tract Infection (UTI) is one of the nosocomial infections that can be experienced by hospitalized patients. One of the causes is the use of catheters. Objective: To identify the duration of catheter use and the incidence of urinary tract infections. Methods: The research is descriptive analytic with cross sectional study approach. The number of samples was 44 people whom were taken using purposive sampling. The criterion of respondent was patient with an indwelling catheter when they were newly admitted to the hospital with a primary diagnosis of not having urinary tract infection. Ethical approval for the research was obtained before data were collected. The data were collected from 22 June 2015 to 22 July 2015 by using observation sheets and examining respondents' urine specimens in the laboratory. They were analyzed through univariate and bivariate using chi square test. Results: $43.2 \%$ of respondents had UTI, 40.9\% did not comply with the rules (more than 7 days) in terms of the duration of catheter use, and there was a significant correlation between the duration of catheter use and incidence of urinary tract infection $(p<0.001)$. Conclusion: Prolonged catheter use has a significant correlation with the incidence of urinary tract infection in patients. The results of this research can be used as a basis for ward nurses in planning periodic supervision and catheter replacement interventions for patients. Keywords: catheter, urinary tract infection, hospital, urinalysis 


\section{LATAR BELAKANG}

Rumah sakit sebagai salah satu sarana kesehatan yang memberikan pelayanan kesehatan kepada masyarakat memiliki peran yang sangat penting dalam meningkatkan derajat kesehatan masyarakat. Oleh karena itu rumah sakit dituntut untuk dapat memberikan pelayanan yang bermutu sesuai dengan standar operasional yang sudah disusun pihak rumah sakit. Rumah sakit sebagai tempat pengobatan, juga merupakan sarana pelayanan kesehatan yang dapat menjadi sumber infeksi (infeksi nosokomial). Infeksi yang ada di pusat pelayanan kesehatan ini dapat ditularkan atau diperoleh melalui petugas kesehatan, orang sakit, pengunjung yang berstatus karier atau karena kondisi rumah sakit (Departemen Kesehatan Republik Indonesia, 2007). Menurut Darmadi (2008), secara umum pasien yang masuk rumah sakit dan infeksi yang baru menunjukkan gejala setelah $3 \times 24$ jam pasien berada di rumah sakit baru disebut infeksi nosokomial. Menurut Tietjen, Bossemeyer, \& McIntosh (2004) berdasarkan survei yang dilakukan, jenis infeksi nosokomial yang sering terjadi di rumah sakit antara lain infeksi saluran kemih, infeksi luka operasi, infeksi saluran cerna, infeksi saluran nafas bawah, febris puerperalis dan bakteremia dan septicemia.

Infeksi saluran kemih merupakan infeksi yang terjadi lebih dari sepertiga seluruh infeksi yang didapat di rumah sakit (Johnson, 1991 dalam Potter, 2006). Menurut Suharyanto \& Madjid (2009), terhitung 6 sampai 7 juta kunjungan klinik setiap tahun pasien mengalami infeksi saluran kemih yang nekrosis jaringan ginjal dan menjadi inti pembentukan batu saluran ginjal. Menurut Hidayanti \& Rachmadi (2008), apabila infeksi saluran kemih (ISK) tidak ditangani dengan baik dan benar maka akan menimbulkan efek jangka panjang seperti parut ginjal yang akhirnya akan mengakibatkan gagal ginjal kronik.

ISK sebagian besar (80\%) mengikuti prosedur invasif atau instrumentasi saluran kemih, yang biasanya berupa kateterisasi (Potter, 2006). Menurut hasil survey yang dilakukan oleh The CDC HealthcareAssociated Infection (HAI) tahun 2011, prevalensi ISK yang disebabkan oleh tindakan invasif di seluruh rumah sakit di Amerika berada pada peringkat ke-3 dari semua jenis penyakit infeksi dengan jumlah 93.300 kasus.

Menurut Semaradana (2014), prevalensi ISK tinggi pada pasien yang memakai kateter yaitu $80 \%$ dan $10 \%-30 \%$ pasien tersebut akan mengalami bakteriuria. ISK akibat kateterisasi merupakan tipe infeksi nosokomial yang mempunyai risiko 3 kali lebih besar lebih lama dirawat di rumah sakit. Tetapi sebagian kasus bakteriuria tidak menampakan gejala klinis, namun ada beberapa gejala yang sering timbul antara lain panas, uretritis, sistisis hingga gejala yang berat sekalipun.

Kateterisasi dapat menjadi tindakan yang menyelamatkan jiwa, khususnya bila traktus urinarius tersumbat atau pasien tidak mampu melakukan urinasi. Kateterisasi juga dapat digunakan dengan indikasi lain, yaitu untuk menentukan perubahan jumlah urin sisa dalam kandung kemih setelah pasien buang air kecil, untuk memintas suatu obstruksi yang menyumbat aliran urin, untuk menghasilkan drainase pascaoperatif pada kandung kemih, daerah vagina atau prostat, atau menyediakan cara-cara untuk memantau pengeluaran urin setiap jam pada pasien sakit berat (Smeltzer \& Bare, 1996/2002).

Berdasarkan teori bahwa penggunaan kateter dalam jangka waktu $<72$ jam dapat mencegah infeksi slauran kemih, sedangkan penggunaan kateter dalam jangka waktu yang lama ( $\geq 72$ jam) dapat menyebabkan resiko 
infeksi saluran kemih. Hal ini memang kurang menjadi perhatian oleh tenaga kesehatan tentang pentingnya penggantian kateter, tanpa disadari hal ini dapat menambah penyakit bagi pasien karena adanya kateter yang terlalu lama yang dapat menyebabkan berkembangnya bakteri (Sitorus, 2012).

Penggunaan kateter kandung kemih menetap, bakteri naik di sepanjang sisi luar kateter pada dinding uretra atau naik ke lumen kateter. Kateter mengganggu mekanisme berkemih normal yang bertindak sebagai pertahanan melawan organisme yang masuk ke dalam uretra. Iritasi lokal pada uretra atau kandung kemih nantinya akan menjadi faktor predisposisi masuknya bakteri ke dalam jaringan (Potter, 2006).

Bakteri dalam urin (bakteriuria) dapat memicu penyebaran organisme ke dalam aliran darah dan ginjal. Mikroorganisme sering masuk ke dalam saluran kemih melalui rute uretra asenden. Bakteri menempati uretra distal, genetalia eksterna dan vagina pada wanita. Organisme masuk ke dalam meatus uretra dengan mudah dan naik ke lapisan mukosa bagian dalam menuju kandung kemih (Yoshikawa, 1993 dalam Potter, 2006).

Menurut Semaradana (2014), sebagian besar bakteri masuk melalui ekstraluminal $(66 \%)$, dapat terjadi inokulasi langsung saat kateter dimasukkan atau dapat terjadi kemudian jika bakteri dari meatus uretra naik (ascend) sepanjang permukaan luar kateter di mukosa periuretra. Mekanisme intraluminal terjadi karena refluks bakteri dari urobag atau dari area pertemuan kateter dengan urobag yang telah terkontaminasi. Bakteri dapat berkolonisasi di dalam kandung kemih dalam 3 hari.

Jika penggunaan kateter lebih lama dari aturan maka akan menjadi tempat yang baik bagi bakteri untuk berkembang biak sehingga kemngkinan infeksi dapat terjadi. Hal ini dapat dilihat dalam penelitian Sitorus (2012) dimana penelitian yang dilakukannya kepada 20 responden, dari 14 responden yang penggunaan kateter tidak sesuai dengan aturan ( $>4$ hari) yang mengalami infeski saluran kemih sebanyak 11 responden.

Sedangkan menurut Hartawan, Taza, \& Sukriyadi (2012) dalam penelitiannya, didapatkan hasil bahwa dari 30 responden, dari 15 responden yang penggunaan kateter tidak sesuai dengan aturan ( $>4$ hari) yang mengalami infeski saluran kemih sebanyak 10 responden.

RSUP Dr. M. Djamil Padang merupakan rumah sakit rujukan di kota Padang bahkan di Sumatera Barat. Di rumah sakit ini memiliki beberapa instalasi rawat inap (IRNA), salah satunya adalah IRNA Non Bedah Penyakit Dalam. Di instalasi tersebut banyak pasien yang mengalami ISK dan ini dapat dilihat dari data yang peroleh dari rekam medik RSUP Dr. M. Djamil Padang, jumlah pasien yang mengalami ISK sebagai diagnosis sekunder pada tahun 2012 sebanyak 180 pasien, tahun 2013 sebanyak 212 pasien, tahun 2014 sebanyak 185 pasien dan tahun 2015 sebanyak 165 pasien. Pada survey awal ditemukan dari 10 orang yang terpasang kateter ( 5 orang $<7$ hari dan 5 orang $\geq 7$ hari) terdapat 2 pasien yang mengalami ISK pada pasien yang terpasang kateter $\geq 7$ hari, dan berdasarkan wawancara langsung dengan beberapa orang perawat mengatakan bahwa rata-rata lamanya penggunaan kateter pada pasien di instalasi tersebut lebih dari $72 \mathrm{jam}$.

Berdasarkan latar belakang di atas maka peneliti tertarik melakukan penelitian tentang Lamanya Penggunaan Kateter Dengan Kejadian Infeksi Saluran Kemih Pada Pasien Terpasang Kateter di ruang rawat penyakit dalam di satu rumah sakit yang berlokasi di kota Padang Sumatera Barat. 


\section{METODE}

Penelitian deskriptif analitik dengan rancangan cross sectional dimana lamanya penggunaan kateter merupakan variabel bebas sedangkan kejadian infeksi saluran kemih sebagai variabel terikat diteliti pada waktu yang sama

Lokasi penelitian dilaksanakan di Irna Non Bedah Penyakit Dalam (HCU, IW, IP) di satu rumah sakit yang berlokasi di kota Padang tanggal 22 Juni-22 Juli 2015.

Sampel diambil dengan teknik pengambilan purposive sampling yaitu suatu teknik penetapan sampel didasarkan pada suatu pertimbangan tertentu yang dibuat oleh peneliti sendiri, berdasarkan ciri atau sifat-sifat populasi yang sudah diketahui sebelumnya (Notoatmodjo, 2010). Jumlah sampel penelitian ini adalah 44 responden dengan kriteria sampel responden yang dipasang kateter saat baru masuk RS dengan diagnosis utama bukan infeksi saluran kemih

Instrumen pengumpulan data yang digunakan dalam penelitian ini dalam bentuk format observasi yang berisi lamanya pasien terpasang kateter, prosedur pelaksanaan pemasangan kateter yang disusun oleh peneliti sendiri berdasarkan buku ajar fundamental keperawatan, dan juga melihat SOP yang ada di rumah sakit, serta jumlah bakteri hasil pemeriksaan urin di laborarorium.

Peneliti mengobservasi responden dari awal pemasangan kateter sampai sampai hari ke-7 pemasangan, kemudian peneliti dibantu oleh perawat ruangan mengambil spesimen urin responden untuk diperiksa di laboratorium. Namun ada juga pasien yang lama penggunaan kateternya kurang dari 7 hari, maka peneliti mengambil spesimen urin responden pada hari terakhir kateter terpasang. Pengambilan spesimen urin dibantu oleh perawat ruangan yang bertugas. Hasil pemeriksaan laboratorium urin responden sebagai data untuk menegakkan diagnosis ISK oleh dokter pada responden yang terpilih di satu rumah sakit yang berlokasi di kota Padang, Sumatera Barat.

Setelah hasil pemeriksaan laboratorium urin responden keluar, peneliti meminta bantuan kepada dokter untuk menentuan ISK pada responden dengan melihat hasil pemeriksaan ditemukannya bakteriuria $\geq 10^{5}$ $\mathrm{cfu} / \mathrm{mL}$.

Pada penelitian ini responden diminta mengisi inform consent dan kerahasian responden selalu dijaga oleh peneliti. Semua responden memperoleh perlakukan yang sama dan peneliti berusaha memperhitungkan manfaat dan tidak menimbulkan kerugian bagi pasien. Penelitian ini juga telah dinyatakan lolos uji etik oleh komite etik dari Fakultas Kedokteran Universitas Andalas, Padang. Hasil pengumpulan diolah, kemudian dianalisis secara univariat dan ditampilkan dalam bentuk distribusi frekuensi. Kemudian diolah secara bivariate dengan menggunakan uji chi square.

\section{HASIL PENELITIAN}

Hasil penelitian ini disajikan dalam dua bagian yaitu hasil analisis univariat dan bivariat. Karakteristik responden yang dipasang kateter di ruang penyakit dalam dapat dilihat pada tabel 1. Sedangkan kejadian infeksi saluran kemih pada responden yang dirawat di ruang penyakit dalam dapat dilihat di dalam tabel 2. Hasil penelitian pada tabel 1 didapat dari 44 responden sebanyak 40,9\% berusia 28-45 tahun dan berjenis kelamin laki-laki (54,5\%).

Dari tabel 2 dapat diketahui bahwa dari 44 responden, sebanyak 43,2\% mengalami Infeksi saluran kemih. 
Tabel 1. Karakteristik Responden Berdasarkan

Umur dan Jenis Kelamin

\begin{tabular}{lll}
\hline Karakterisitik Responden & Frekuensi (f) & Persentase (\%) \\
\hline 1. Umur & & \\
a. 28-45tahun & 18 & 40,9 \\
b. 46-59 tahun & 14 & 31,8 \\
c. $\geq 60$ tahun & 12 & 27,3 \\
\hline Jumlah & 44 & 100 \\
\hline 2. Jenis Kelamin & & \\
a. Laki-laki & 24 & 54,5 \\
b. Perempuan & 20 & 45,5 \\
\hline Jumlah & 44 & 100 \\
\hline
\end{tabular}

Tabel 2. Distribusi Frekuensi Kejadian Infeksi Saluran Kemih

Di Rung Penyakit Dalam

\begin{tabular}{ccc}
\hline Kejadian ISK & Frekuensi (f) & Persentase (\%) \\
\hline Tidak terjadi ISK & 25 & 56,8 \\
Terjadi ISK & 19 & 43,2 \\
\hline Total & 44 & 100 \\
\hline
\end{tabular}

Tabel 3. Distribusi Frekuensi Lamanya Penggunaan Kateter di Ruang Penyakit Dalam

\begin{tabular}{ccc}
\hline $\begin{array}{c}\text { Lamanya Penggunaan } \\
\text { Kateter }\end{array}$ & Frekuensi (f) & Persentase (\%) \\
\hline Sesuai Aturan (<7 hari) & 26 & 59,1 \\
Tidak Sesuai Aturan ( $\geq 7$ hari) & 18 & 40,9 \\
Total & 343 & 100 \\
\hline
\end{tabular}

Tabel 4. Distribusi Frekuensi Lamanya Penggunaan Kateter dengan Kejadian Infeksi Saluran Kemih di Ruang Penyakit Dalam

\begin{tabular}{|c|c|c|c|c|c|c|c|}
\hline \multirow{3}{*}{$\begin{array}{c}\text { Lamanya } \\
\text { Penggunaan } \\
\text { Kateter }\end{array}$} & \multicolumn{4}{|c|}{ Kejadian ISK } & \multirow{2}{*}{\multicolumn{2}{|c|}{ Total }} & \multirow[b]{3}{*}{$p<0,001$} \\
\hline & \multicolumn{2}{|c|}{ Tidak } & \multicolumn{2}{|c|}{$\mathrm{Ya}$} & & & \\
\hline & $f$ & $\%$ & f & $\%$ & $n$ & $\%$ & \\
\hline Sesuai Aturan & 21 & 80,8 & 5 & 19,2 & 26 & 100 & \\
\hline \multirow{2}{*}{$\begin{array}{c}\text { Tidak Sesuai } \\
\text { Aturan }\end{array}$} & 4 & 22,2 & 14 & 77,8 & 18 & 100 & \\
\hline & 25 & 59,1 & 19 & 40,9 & 44 & 100 & \\
\hline
\end{tabular}


Lamanya penggunaan keteter pada responden yang dirawat di ruang penyakit dalam dapat dilihat di tabel 3 . Hasil penelitian pada tabel 3 didapat dari 44 responden sebanyak 40,9\% lamanya pemasangan kateter tidak sesuai aturan. Hasil analisis bivariat hubungan lamanya penggunaan kateter pada responden degan kejadian ISK dapat dilihat pada tabel 4.

Hasil penelitian pada tabel 4, didapatkan dari 18 responden yang memakai kateter tidak sesuai aturan mengalami ISK $(77,8 \%)$ dibandingkan yang tidak mengalami ISK $(22,2 \%)$. Dari hasil uji statistik diperoleh terdapat hubungan bermakna antara status lamanya pemsangan kateter dengan kejadian ISK $(p<0,001)$.

\section{DISKUSI}

Dari penelitian ini diperoleh bahwa 40,9\% pasien berusia $28-45$ tahun dan $54,5 \%$ berjenis kelamin laki-laki. Berdasarkan teori infeksi saluran kemih dapat menyerang pasien dari segala usia mulai bayi baru lahir hingga orang tua (Purnomo, 2009). ISK pada umumnya lebih sering menyerang wanita daripada pria. Namun pada masa neonatus ISK lebih banyak pada bayi lakilaki $(2,7 \%)$ yang belum menjalani sirkumsisi dari pada bayi perempuan $(0,7 \%)$. Dengan bertambahnya usia, insiden ISK terbalik dimana pada masa sekolah ISK pada anak perempuan 3\% dan laki-laki 1,1\%. Pada usia remaja kejadian ISK pada perempuan meningkat 5,8\%. Bakteri pada usia $18-40$ tahun $5-6 \%$ dan meningkat menjadi $20 \%$ pada usia lanjut (Purnomo, 2009). Menurut O' Callaghan (2006/2009), ditinjau dari jenis kelamin, ternyata pada wanita lebih rentan terjadi ISK daripada laki-laki. Hal ini dipengaruhi oleh faktor anatomi, karena uretra wanita lebih pendek dan terletak dekat dengan anus sedangkan laki-laki bermuara pada saluran kelenjar prostat. Namun hal ini bertolak belakang dengan hasil penelitian yang didapat, dimana pada laki-laki yang terjadi ISK lebih tinggi dibanding pada wanita. Hal ini tidak sesuai dengan hasil penelitian dimana pada penelitian ini yang menderita ISK lebih banyak pada laki laki. Berdasarkan analisis peneliti, hal ini dapat terjadi karena faktor dari lamanya pasien terpasang kateter.

Banyak faktor yang menyebabkan seeorang terserang ISK dan salah satunya adalah dari pemasangan kateter baik dari proses maupun dari lama terpasang dan prosedur perawatan yang dilakukan selama terpasang kateter (Purnomo, 2009). Jika dilihat lebih lanjut dari hasil penelitian ini dari $43,2 \%$ pasien yang mengalami ISK, $68,42 \%$ nya adalah pasien usia lanjut. Sehingga hasil ini sesuai dengan teori yang menyatakan bahwa prevalensi ISK makin meningkat seiring bertambahnya usia. Prevalensi ISK yang tinggi pada usia lanjut dapat disebabkan oleh sisa urin dalam kandung kemih meningkat akibat pengosongan kandung kemih kurang efektif, mobilitas mobilitas menurun, ataupun sistem imunitas menurun baik seluler paupun humoral (Purba, 2012).

Penelitian ini menemukan bahwa lebih dari setengah jumlah responden $(77,8 \%)$ dari $43,2 \%$ responden yang mengalami infeksi akibat lamanya penggunaan kateter yang tidak sesuai aturan. Hal ini sejalan dengan penelitian Semaradana (2014) yang menunjukan infeksi saluran kemih akibat kateterisasi terjadi karena pemasangan kateter dalam jangka waktu lama di RSU Denpasar Bali (Semaradana, 2014).

Pemasangan kateter merupakan satu solusi tindakan medis untuk mengeluarkan urin dari kandung kemih seseorang karena ketidakmampuan pengeluaran urin secara spontan. Pemasangan keteter akan menimbulkan dampak yang merugikan terutama untuk pasien yaitu terjadi infeksi nosokomial saluran kemih (ISK). ISK yang 
didapat di institusi kesehatan timbul akibat buruknya praktek cuci tangan pada petugas kesehatan, cairan irigasi yang terkontaminasi dan teknik kateterisasi yang tidak benar, sebagian besar infeksi ini (sedikitnya 80\%) mengikuti prosedur invasif atau instrumentasi saluran kemih, yang biasanya berupa kateterisasi (Potter, 2006).

Menurut Potter (2006), pemasukan kateter melalui uretra akan menyediakan rute langsung masuknya mikroorganisme. Dengan menggunakan kateter kandung kemih menetap, bakteri naik di sepanjang sisi luar kateter pada dinding uretra atau naik ke lumen kateter. Kateter mengganggu mekanisme berkemih normal yang bertindak sebagai pertahanan melawan organisme yang masuk ke dalam uretra. Iritasi lokal pada uretra atau kandung kemih nantinya akan menjadi faktor predisposisi masuknya bakteri ke dalam jaringan.

Menurut Smeltzer \& Bare (1996/2002), pada pasien yang menggunakan kateter mikroorganisme dapat menjangkau traktus urinarius melalui 3 lintasan utama, yaitu: a) dari uretra ke dalam kandung kemih pada saat kateterisasi, b) melalui jalur dalam lapisan tipis cairan uretra yang berada di luar kateter ketika kateter dan membran mukosa bersentuhan, 3) cara yang paling sering melalui migrasi ke dalam kandung kemih di sepanjang lumen internal kateter setelah kateter terkontaminasi.

Menurut analisis peneliti responden yang mengalami ISK disebabkan oleh tidak sesuainya waktu pemasangan kateter yaitu lebih dari 7 hari karena dapat menjadi media tempat berkembangnya bakteri.

Kelemahan penelitian ini adalahmpeneliti hanya menilai lamanya pemasangan kateter dengan kejadian infeksi saluran kemih, dan secara secara teoritis banyak faktor yang bisa menyebabkan seseorang mengalami infeksi dan faktor-faktor tersebut belum dilihat lebih mendalam pada penelitian ini. Hal ini terbukti dari hasil penelitian dimana ada beberapa responden yang terpasang kateter sesuai aturan juga mengalami infeksi saluran kemih.

Implikasi dalam keperawatan pada penelitian ini adalah dimana hasil penelitian ini dapat menunjukkan pada perawat bahwa perawatan kateter dan penggantian kateter secara periodik sangat dibutuhkan terutama pada pasien hari rawatan yang lama dengan penggunaan kateter dalam jangka waktu yang lama juga, sehingga diharapkan perawat dapat melakukan perawatan kateter yang tepat dan juga mengganti kateter pasien dengan baik sesuai aturan.

\section{SIMPULAN}

Hasil Penelitian ini menunjukkan terdapat pasien rawat yang mengalami infeksi saluran kemih dan terdapat pasien menggunakan kateter yang tidak sesuai aturan ( $>7$ hari). Terdapat hubungan antara lamanya penggunaan kateter dengan kejadian infeksi saluran kemih.

Bagi perawat ruangan, disarankan untuk dapat meningkatkan pelayanan dalam hal pemasangan kateter pasien, melakukan perawatan kateter dengan baik dan benar selama pasien terpasang kateter, serta memperhatikan lebih serius dalam pengawasan dan pergantian kateter secara periodik.

\section{DAFTAR PUSTAKA}

Darmadi. (2008). Infeksi nasokomial: Problematika dan pengendaliannya. Jakarta: Erlangga.

Departemen Kesehatan Republik Indonesia. (2007). Pedoman pencegahan dan penanggulangan infeksi di rumah sakit dan fasilitas kesehatan lainnya. Jakarta: Departemen Kesehatan Republik Indonesia. 
Hartawan, M., Taza, H. \& Sukriyadi. (2012). Hubungan antara pemasangan kateter dengan kejadin infeksi saluran kemih pada pasien rawat inap di RSUD Lapatarai kabupaten Baru. Jurnal STIKES Nani Hasanuddin Makasar, 1(4): 1-8.

Hidayanti, E. \& Rachmadi, D. (2008). Infeksi saluran kemih kompleks. Retrieved from: http://repository.unpad.ac.id/17729/1/ Pustaka_Unpad_ISK_-Kompleks.pdf. pdf

Notoatmodjo, S. (2010). Metodologi penelitian. Jakarta: Rhineka Cipta.

O'Callaghan, C. A. (2009). At a Glance Sistem Ginjal (Edisi 2). (Alih Bahasa: Yasmin, E). Jakarta: Erlangga. (Buku asli diterbitkan 2006).

Potter, P. A. (2006). Fundamentals of Nursing: Concepts, process, and practice ( $4^{\text {th }}$ edition). (Alih bahasa: Renata Komalasari). Jakarta: Buku Kedokteran EGC.

Purba, R. (2012). Faktor-faktor yang mempengaruhi terjadinya infeksi saluran kemih pada pasien terpasang kateter menetap di RS Haji Medan. FK USU (Skripsi). Universitas Sumatera Utara, Medan, Indonesia.

Purnomo, B. (2009). Dasar-dasar urologi (Edisi 2). Jakarta: Sagung Seto.

RSUP Dr. M. Djamil Padang. (2011). Standar prosedur operasional pemasangan kateter urine. Tidak dipublikasikan.

Semaradana, W. G. P. (2014). Infeksi saluran kemih akibat pemasangan kateter diagnosis dan penatalaksanaannya. CDK-221, 41(10): 737-740.

Sitorus, F. E. (2012). Hubungan lamanya penggunaan kateter terhadap terjadinya infeksi saluran kemih. Jurnal Keperawatan Sekolah Tinggi IImu Kesehatan Deli Husada, 1(2): 37-41.
Smeltzer, S. C. \& Bare, B. G. (2002). Brunner and Suddarth's textbook of medical surgical nursing ( $8^{\text {th }}$ edition). (Alih bahasa: Agung Waluyo, Yasmin Asih, Juli, Kuncara, I Made Kariasa). Jakarta: Penerbit Buku Kedokteran EGC. (Buku asli diterbitkan 1996).

Suharyanto, T. \& Madjid, A. (2009). Asuhan keperawatan pada klien dengan gangguan sistem perkemihan. Jakarta: Trans Info Media.

Tietjen L., Bossemeyer, D., \& Mclntosh, N. (2004). Infection prevention guidelines for healthcare facilities with limited resources. (Alih bahasa: Abdul Bari Saifuddin, Sudraji Sumapraja, Djajadilanga, Budi Imam Santoso). Jakarta: Yayasan Bina Pustaka Sarwono Prawiroharjo. (Buku asli diterbitkan 2003).

The CDC Healthcare-Associated Infection (HAI). (2011). HAl data and statistics. Retrieved from http://www.cdc.gov/HAl/ surveillance/ 